\title{
Past for the Future and Future for the Past: Preservation and Promotion of the World Heritage Sites. An Introduction
}

Cultural Heritage is a common resource of people across the world, representing humanity's relationship with the past and its traditions. Cultural heritage is diverse, and people have a common responsibility to understand and safeguard it for future generations (cf. ICOMOS, Venice Charter 1964). The UNESCO, Council of Europe and other international organizations have adopted several conventions in the area of cultural heritage preservation that set common rules and standards. All signatory countries have accordingly accepted to establish efficient management of and to safeguard the cultural heritage. As such, cultural heritage emerges as a key element of individual and social well-being, and its protection, management and planning entail rights and responsibilities for everyone.

Since 1972 UNESCO has established a frame of protection for cultural and natural heritage (Convention concerning the protection of the World Cultural and Natural Heritage) and the "World Heritage List", which it considers as having outstanding universal value, now (2019) listing 1121 properties from 167 countries, including 869 cultural sites, 213 natural and 39 mixed sites. In 1994, at the Nara Conference the Document on Authenticity was established, stating that "the protection and enhancement of cultural and heritage diversity in our world should be actively promoted as an essential aspect of human development". Today, many factors affect the authenticity and integrity of cultural heritage: intensive tourism, over-restoration works, new inappropriate investments or uncorrelated private interventions, etc. The debates on cultural heritage research, preservation and management have increased in recent years as the effect of UNESCO standards, namely to establish "an effective system of collective protection of the cultural and natural heritage of outstanding universal value, organized permanently and in accordance with modern scientific methods". The problem of preservation, management and promotion of heritage is actual and important from many points of views: scientific, technologic, socio-economic, and cultural ones. Taking into account the actuality and importance of the World Heritage, under the auspices of the Institute of Archaeology, Romanian Academy, Iași branch, we achieved in 2017-2019 a new project „Preservation by the development of sustainable strategies for better protection of the World Heritage Sites from Romania”, supported by National Research Council (CNCS) - Executive Agency for 


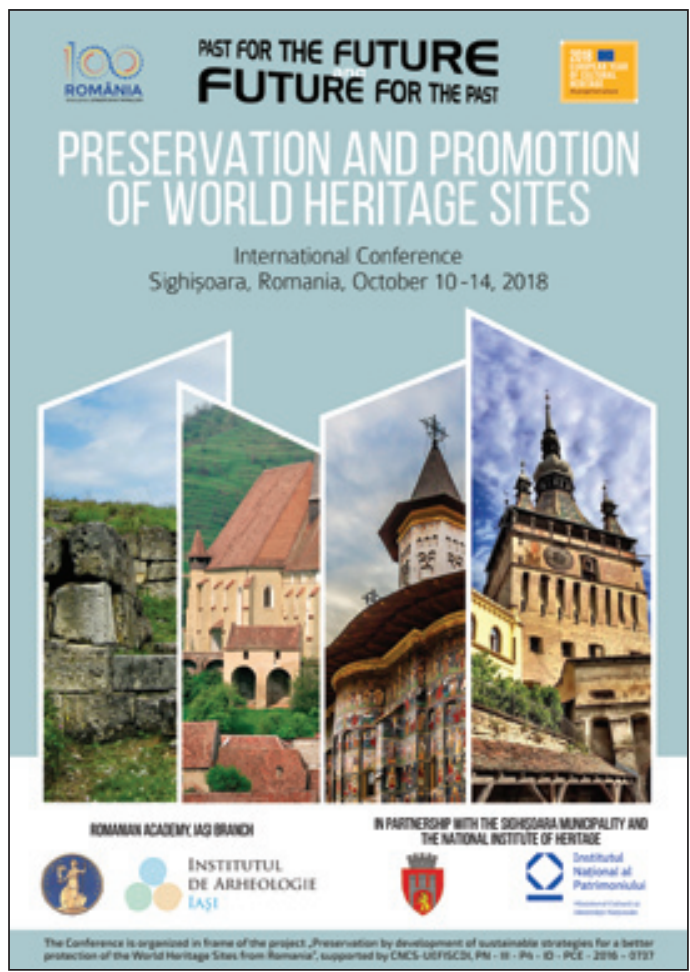

Higher Education, Research, Development and Innovation Funding (UEFISCDI). The main goal of the project was to identify and set up innovative models of good practices, adapted to the local cultural and social-economic specificities, for safeguarding and managing the Romanian World Heritage Sites. Through this project, we developed an experienced team with an extended professional network, which investigated the best practices for the World Heritage Sites sustainable management and transfer of the knowledge, for improving the situation in Romania. Another objective was to assess the real state of the World Heritage Sites from Romania, identify the main problems and find adequate solutions for better preservation and conservation. The analysis was based on actual criteria of evaluation, conservation and management of the World Heritage Sites.

As part of the project we organised in 2018 an International Conference "Past for the Future and Future for the Past: Preservation and Promotion of the World Heritage Sites”, in 2018, October 10-14, in Sighișoara, the World Heritage City from Romania. The main goal of the conference was sharing the knowledge and experience of good management practices of the World Heritage Sites with colleagues from various countries around the world. The Conference was organised in close cooperation with the Sighișoara municipality and the National Institute of Heritage and brought together over 40 experts in heritage from Austria, Germany, Hungary, the Netherlands, the Republic of Moldova, Romania, Russia, the United Kingdom, and the USA. During three days, the participants debated various topics related to the World Heritage Management, including study trips to some World Heritage Sites from Romania. Most of the participants in the conference mentioned that the process of evaluation, preservation and management of the sites has to involve all interested parties - national, regional and local ones, with the participation of scholars and local 
communities from the same level to different ones (horizontal to vertical integration). Only a common and integrated approach will make it possible to enrich UNESCO standards of preservation and maintain the World Heritage Site status. The integration approach is the

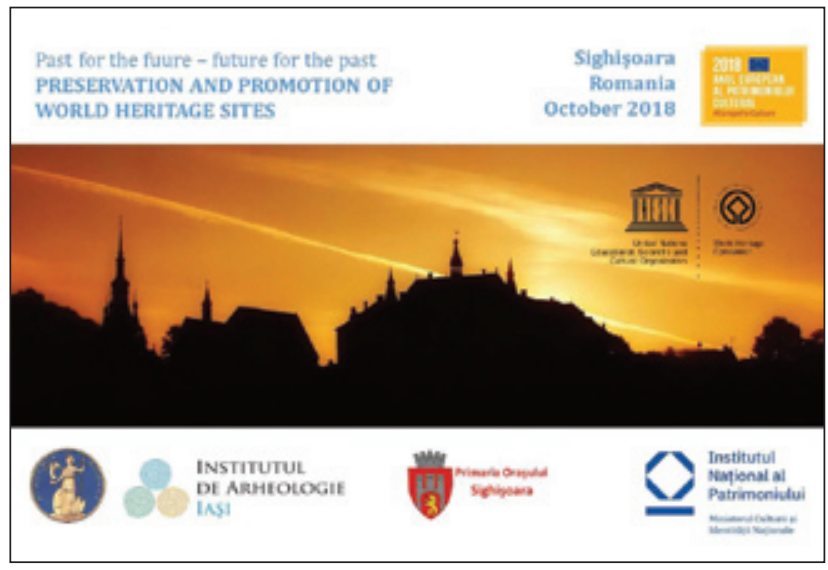
only adequate way to sustainably manage the World Heritage Sites. Furthermore, the need for a relevant, balanced and realistic approach is strongly encouraged by UNESCO in the Operational Guidelines for implementation of the World Heritage Convention. Preservation strategies and management plans should be based on the following areas: physical protection, making visible, remember and refers, presentation of the content and sites' branding. Cultural sites protection and management should be a complex approach and followed the principle the Preservation by developing sustainable strategies of the World Heritage List. Sustainable site management should be followed by a permanent consultation process between responsible bodies, professional and local communities.

Protection of authentic heritage recognised by UNESCO was reconfirmed at the $39^{\text {th }}$ Session of the World Heritage Committee in Bonn, Germany (2015). Participants pointed out the need to review the state of conservation of World Heritage Sites and inscribe new sites on the World Heritage List. In this context, we need a critical approach to the real situation of each site, starting a discussion on a Policy Document for World Heritage Sites preservation and promotion, and establishing a model for heritage management according to the needs and specificities of each site. This process should involve public debates and discussions on how it might be possible to improve all aspects related to these sites. Research should play an important role in this process and UNESCO encourages States Parties to make resources available to research knowledge and understanding are fundamental to the identification, management, and monitoring of World Heritage properties.

Recent Resolution of the United Nations Security Council 2347 (2017) just confirms the role of cultural heritage in maintaining international peace and security. Therefore, all countries have to take in consideration that the defence of cultural heritage is more than a cultural issue, it is a security imperative, 
inseparable from defending human life. Only a common and integrated approach will make it possible to enrich UNESCO standards of preservation and maintain the World Heritage.

The editing committee of our journal decided to publish in two issues the proceedings of the International Conference "Past for the Future and Future for the Past: Preservation and Promotion of the World Heritage Sites", October 10-14, 2018, Sighișoara, Romania.

We thank the National Research Council (CNCS) - Executive Agency for Higher Education, Research, Development and Innovation Funding (UEFISCDI), and the partners (the Sighișoara municipality and the National Institute of Heritage), who made the organisation of the conference possible. Special acknowledgements are addressed to all colleagues who contributed to this conference.

Sergiu Musteață, project director 